\title{
Rabies in the Critical Care Unit: Diagnostic and Therapeutic Approaches
}

\author{
Alan C. Jackson
}

\begin{abstract}
Worldwide, human rabies is prevalent where there is endemic dog rabies, but the disease may present unexpectedly in critical care units when suggestive clinical features have passed. In North America transmission from bats is most common and there is often no history of a bat bite or even contact with bats. Laboratory diagnostic evaluation for rabies includes serology plus skin biopsy, cerebrospinal fluid, and saliva specimens for rabies virus antigen and/or RNA detection. Rare patients have survived rabies, and most received rabies vaccine prior to the onset of illness. Therapeutic coma (midazolam and phenobarbital), ketamine, and antiviral therapies (dubbed the "Milwaukee Protocol") were given to a rabies survivor, but this therapy was likely not directly responsible for the favorable outcome. There have been many subsequent failures of similar therapeutic approaches. There is no scientific rationale for the use of therapeutic coma in human rabies. New approaches to treating human rabies need to be developed.
\end{abstract}

\begin{abstract}
RÉSUMÉ: La rage : diagnostic et options thérapeutiques à l'unité de soins intensifs. À travers le monde, la rage chez l'humain est courante là où elle est endémique chez le chien. La maladie peut se présenter de façon inattendue à l'unité de soins intensifs lorsque les manifestations cliniques typiques de la maladie ne sont plus présentes. En Amérique du Nord, le vecteur le plus fréquent est la chauve-souris et ce souvent sans histoire de morsure ou de contact avec une chauve-souris. Le diagnostic de la rage est posé par sérologie avec biopsie cutanée et analyse du liquide céphalorachidien et de la salive pour la détection de l'antigène et/ou de l'ARN du virus de la rage. Quelques rares patients ont survécu à la rage et la plupart avaient reçu le vaccin contre la rage avant le début de la maladie. Un survivant de la rage a été traité par coma thérapeutique (midazolam et phénobarbital), kétamine et antiviraux (le "protocole de Milwaukee"). Cependant, ce traitement n'était vraisemblablement pas responsable de l'issue favorable chez ce patient. Par la suite, il y a eu plusieurs échees avec des protocoles de traitement similaires. Il n'existe pas de justification scientifique de l'utilisation du coma thérapeutique dans le traitement de la rage chez l'humain. Il faut que nouvelles approches thérapeutiques pour traiter la rage chez l'humain soient développées.
\end{abstract}

Can. J. Neurol. Sci. 2011; 38: 689-695

Rabies may be difficult to diagnose in the critical care unit. Early clinical features, which may have been suggestive of rabies, may no longer be present. In North America the absence of a history of an animal exposure is not unusual. The laboratory diagnosis of rabies requires that rabies be considered clinically and then the appropriate specimens can be collected and sent to a rabies diagnostic laboratory. Health care workers should be protected with barrier techniques whenever the diagnosis is suspected. Rabies is almost invariably fatal, but aggressive approaches to therapy should be considered in selected cases because there have been a small number of survivors.

\section{Pathogenesis and Pathology}

Rabies virus is a single-strand RNA virus in the virus family Rhabdoviridae and genus Lyssavirus. Under normal conditions rabies virus is transmitted in saliva containing infectious rabies virus from a bite by an animal vector. The key sequential steps in rabies pathogenesis are shown in Figure 1. During most of the incubation period, usually lasting weeks or months, the virus is probably located close to the site of entry. Rabies virus binds to the nictotinic acetylcholine receptor at the neuromuscular junction. ${ }^{1}$ The virus spreads towards the central nervous system (CNS) in the axons of peripheral nerves by retrograde fast axonal transport (about $250 \mathrm{~mm} /$ day). ${ }^{2}$ In the CNS the virus is also transported within axons by fast axonal transport along neuroanatomical connections ${ }^{3}$ and quickly becomes

From the Departments of Internal Medicine (Neurology) and of Medical Microbiology, University of Manitoba, Winnipeg, Manitoba, Canada.

Received March 23, 2011. Final Revisions Submitted AprIL 26, 2011 Correspondence to: Alan C. Jackson, Health Sciences Centre, GF-543, 820 Sherbrook Street, Winnipeg, Manitoba, R3A 1R9, Canada 
disseminated throughout the CNS. Subsequently, the virus travels centrifugally along autonomic and sensory pathways to multiple organs, including the salivary glands, heart, adrenal medulla, and skin. ${ }^{4}$ This is important for the development of salivary gland infection in rabies vectors and also for human diagnosis using skin biopsies. ${ }^{5,6}$ There may be infection of cardiac ganglia and the myocardium ${ }^{4}$ and, in some cases, there is a myocarditis. ${ }^{7-9}$

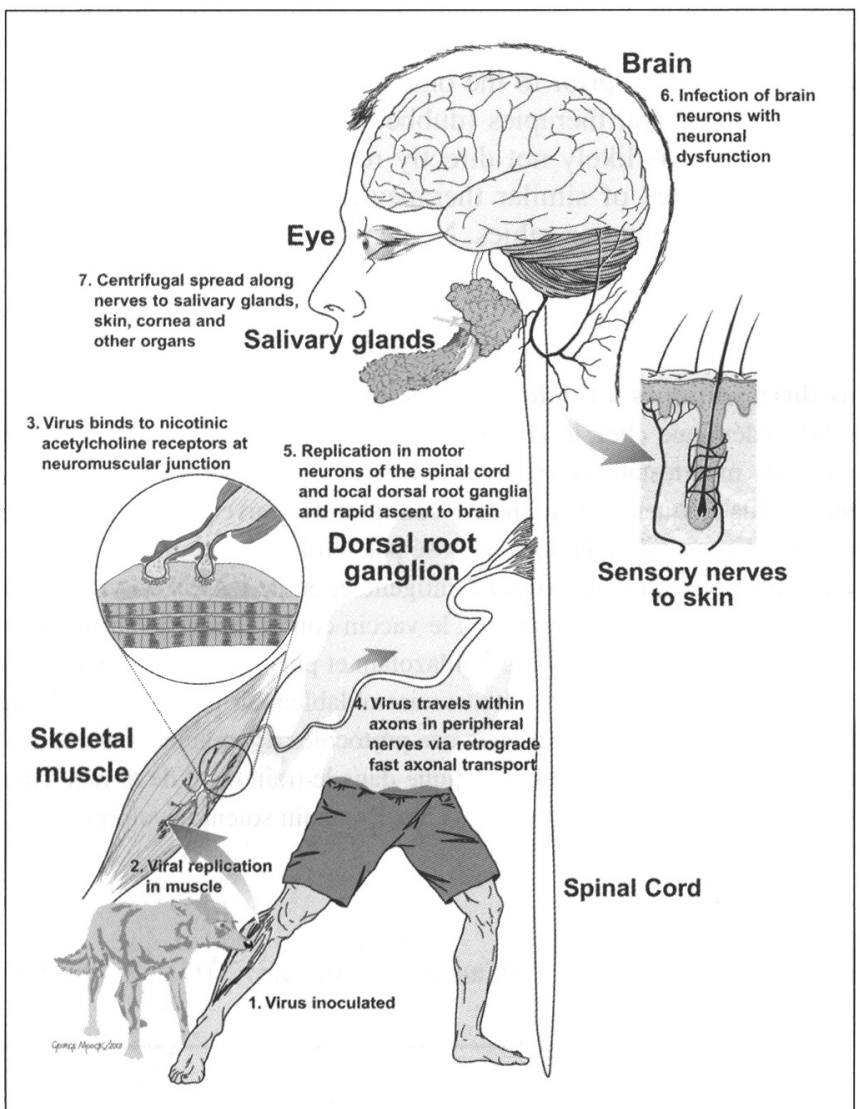

Figure 1: Schematic diagram showing the sequential steps in the pathogenesis of rabies after an animal biteiperipheral inoculation of rabies virus. (Reproduced from Jackson AC: Pathogenesis, in Rabies, edited by AC Jackson and WH Wunner, 2002, Academic Press, San Diego, pp 345-82, ${ }^{10}$ Copyright Elsevier).

In rabies there are mild inflammatory changes in the CNS. Neurons are the neural cell type predominantly infected by rabies virus and there are few degenerative changes in neurons. Infected neurons may contain eosinophilic inclusions in the cytoplasm called Negri bodies (Figure 2). Negri bodies are most prominent in large neurons (e.g., Purkinje cells) and, ultrastructurally, they are composed of large aggregates of granulo-filamentous matrix material and variable numbers of viral particles. ${ }^{11}$

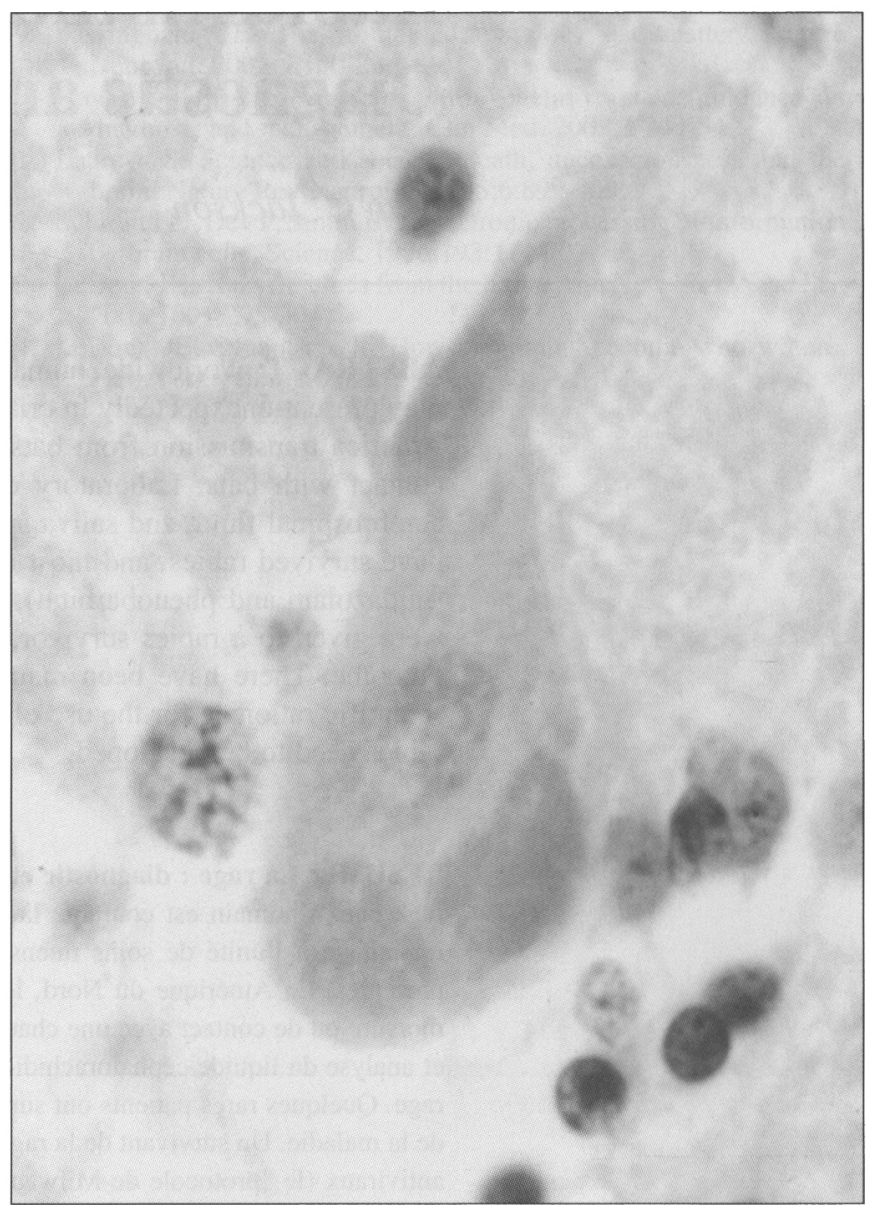

Figure 2: Three large Negri bodies in the cytoplasm of a cerebellar Purkinje cell from an eight year-old boy who died of rabies after being bitten by a rabid dog in Mexico. (Reproduced with permission from AC Jackson, E Lopez-Corella, $N$ Engl I Med 335:568, 1996; ${ }^{2}$ Copyright Massachusetts Medical Society).

\section{EPIDEMIOLOGY}

Rabies remains an important public health problem in resource-limited and resource-poor countries, particularly in Asia and Africa. This situation occurs because dog rabies is endemic with dog-to-dog transmission of the infection, which is associated with an ongoing threat to humans due to dog bites. Unfortunately, children share a disproportionately high burden of the disease. There are probably about 75,000 human deaths per year worldwide from rabies. In North America wildlife rabies is present in bats and in a number of terrestrial species, including skunks, raccoons, and foxes ${ }^{13}$ (Figure 3). Most indigenously acquired human cases in North America are caused by rabies virus variants associated with insectivorous bats. Most important for causing human rabies is a variant isolated from silver-haired (Lasionycteris noctivagans) and eastern pipistrelle (Pipistrellus subflavus) bats, which are small bats and may explain the failure to recognize bites from these species. Less commonly, human rabies may be due to a variant from Brazilian 
(also called Mexican) free-tail bats (Tadarida braziliensis) and also to variants associated with other bat species. Bat bites may appear trivial and not be recognized (Figure 4) or there may even be no known exposure to bats. The majority $(60 \%)$ of human cases of rabies due to bat variants in the United States and Canada do not give a history of a bat bite or scratch and $33 \%$ have no history of contact with bats at all. ${ }^{14}$ Hence, the absence of a history of an animal bite or even the absence of a history of contact with bats is common in association with human rabies cases. Of the last seven human cases of rabies that have occurred in Canada since 1970 , all except one $(6 / 7$ or $86 \%)$ were transmitted by insectivorous bats (Table 1).

Table 1: Fatal human cases of rabies in Canada, 1970 - 2010

\begin{tabular}{|c|c|c|c|c|}
\hline Year & $\begin{array}{l}\text { Age and Sex } \\
\text { of Patient }\end{array}$ & Province & Vector & References \\
\hline 1970 & 15 male & Saskatchewan & bat & Demster et al $(1972)^{15}$ \\
\hline 1977 & 63 male & Nova Scotia & bat & King et al $(1978)^{16}$ \\
\hline 1984 & 43 male & Quebec & dog (Dominican Republic) & Picard $(1984)^{17} ;$ Webster et al $(1985)^{18}$ \\
\hline 1985 & 25 male & Alberta & bat & $\begin{array}{l}\text { Dolman and Charlton }(1987)^{19} ; \text { Webster et al } \\
(1987)^{20}\end{array}$ \\
\hline$\underline{2000}$ & 9 male & Quebec & bat & Turgeon et al $(2000)^{21}$; Despond et al $(2002)^{22}$ \\
\hline 2003 & 52 male & British Columbia & bat & Parker et al $(2003)^{23}$ \\
\hline 2007 & 73 male & Alberta & Bat & McDermid et al $(2008)^{24}$ \\
\hline
\end{tabular}

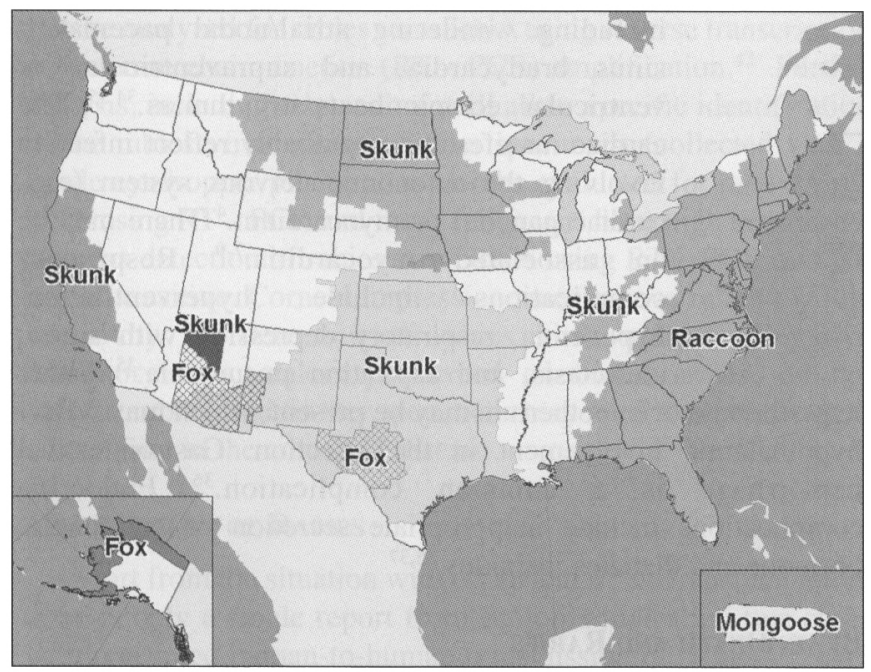

Figure 3: Distribution of the major rabies virus variants among wild terrestrial reservoirs in the United States and Puerto Rico, 2008 (From JD Blanton et al, J Am Vet Med Assoc 235:676-89, 2009,,25 Centers for Disease Control and Prevention)
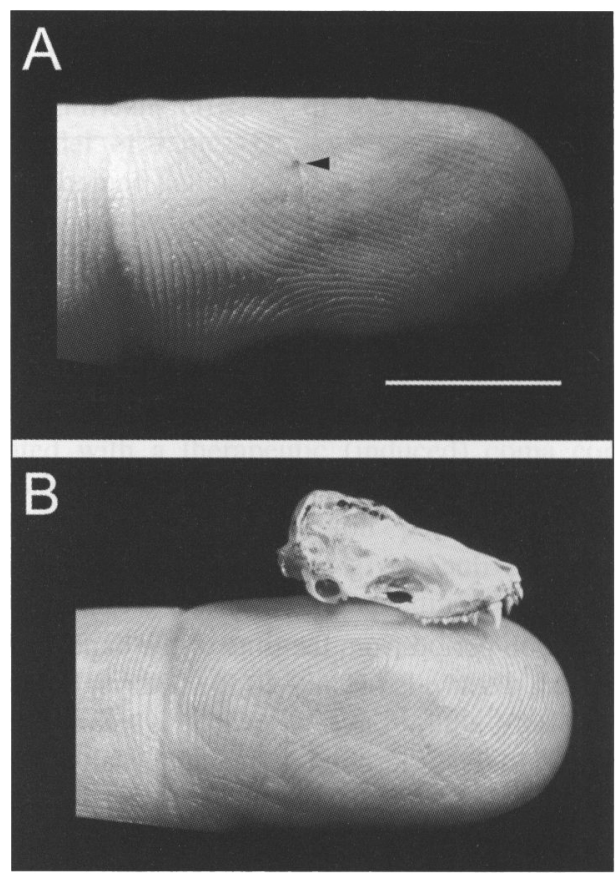

Figure 4: Small puncture wound (arrowhead) involving the right ring finger of a bat biologist $(A)$ caused by a defensive bite from a canine tooth of a silver-haired bat (Lasionycteris noctivagans) (Bar $=10 \mathrm{~mm})$. Skull of a silver-haired bat $(B)$ (length of $17.1 \mathrm{~mm}$ ) is resting on a distal phalanx, which demonstrates the small size of the bat and its teeth. (Reproduced with permission from Jackson and Fenton in Lancet $357: 1714,2001 ; ;^{26}$ Copyright Elsevier) 
In 2004 there were four iatrogenic rabies cases in Texas resulting from transplantation of organs and a vascular conduit; ${ }^{27,28}$ three cases occurred in Germany in 2005 due to organ transplantation ${ }^{29}$ (Table 2 ) . In addition, there are eight well-documented cases of rabies transmitted by corneal transplantation ${ }^{30}$ and there also were three cases associated with corneal transplantation from donors with rabies in which the recipients did not develop rabies. ${ }^{31,32}$ Clinical screening of organ and tissue donors is important, but laboratory screening for rabies is problematic because of time limitations, a variety of logistical issues, and difficulties associated with false positive results, which would lead to wastage of valuable organs in a situation in which there is already a serious shortage of available organs for transplantation. but there is likely greater burden of disease in paralytic rabies involving the spinal cord, spinal nerve roots, and peripheral nerves, whereas in encephalitic rabies the burden of disease is greater in the brain. In encephalitic rabies there are often episodes of generalized arousal or hyperexcitability separated by lucid intervals. ${ }^{33}$ Autonomic dysfunction is common and includes hypersalivation, piloerection (gooseflesh), cardiac arrhythmias, and priapism. The most characteristic feature is hydrophobia, which involves spasms of the diaphragm and other inspiratory muscles (lasting 5-15 seconds) on attempts to swallow. This is reinforced by conditioning and the sight of liquids may precipitate spasms. A draft of air can also produce spasms (aerophobia). The disease progresses with development of stupor and coma, quadriparesis, and organ failure, which requires management in a critical care setting.

Paralytic rabies usually begins with paresis in the bitten extremity with spread to quadriparesis and bilateral facial weakness. Sphincters are often affected and there is usually minimal sensory involvement. Hydrophobia does not normally develop in paralytic rabies. There is progression of paralytic rabies to coma and organ failure, typically with a longer clinical course than in encephalitic rabies.

\section{Medical Complications}

Cardiac disorders are common medical complications of rabies, which may occur in a critical care unit. Sinus tachycardia is very common and the heart rate is often greater than would be expected for the degree of fever.$^{34}$ Heart failure, hypotension, and cardiac arrest may occur as well as a variety of cardiac arrhythmias, including wandering atrial/nodal pacemaker, sinus bradycardia, and supraventricular or ventricular ectopic beats/arrhythmias. ${ }^{34,35}$ The cardiac manifestations probably reflect infection involving the autonomic nervous system (e.g., cardiac ganglia) or myocardium. ${ }^{4}$ There may be an associated myocarditis. ${ }^{7-9}$ Respiratory complications include hyperventilation, hypoxemia, respiratory depression with apnea, atelectasis, and aspiration pneumonia. ${ }^{35}$ Either hyperthermia or hypothermia may be present, which may reflect hypothalamic involvement in the infection. Gastrointestinal hemorrhage is a common complication. ${ }^{36}$ Endocrine complications include inappropriate secretion of antidiuretic hormone and diabetes insipidus..$^{35,37}$

\section{Brain Death and Rabies}

A Canadian case of rabies has illustrated that patients with rabies may remain for a prolonged period in a brain death-like state; survival has never been reported in this setting. In Edmonton a patient with rabies was maintained in a therapeutic coma from 15 to 42 days after symptom onset, and he remained comatose for over three weeks after the sedation was discontinued..$^{24}$ On Day 43 an electroencephalogram was "near isoelectric." On Day 64 a neurologic examination and apnea 
testing were consistent with brain death, and a nuclear medicine perfusion scan showed "preservation of cerebral blood flow."24 Supportive care was withdrawn and he died on Day 65; autopsy showed "complete neuronal loss" in the cerebral cortex ${ }^{24}$ and also extensive neuronal loss in the brainstem (Dr. Christopher Power, personal communication). This case illustrates that rabies is a disorder in which brain blood flow may be preserved in association with brain death.

\section{LABORATORY INVESTIGATIONS}

A clinical suspicion of rabies is necessary in order to initiate the appropriate diagnostic laboratory tests for rabies. Routine blood work is generally not helpful. Computed tomogram (CT) imaging of the brain is only useful to exclude other diseases. Magnetic resonance imaging (MRI) of the brain may be normal or may show lesions in gray matter areas of the brain parenchyma, including the brainstem. ${ }^{38-41}$ Cerebrospinal fluid (CSF) analysis often shows a mild mononuclear pleocytosis (less than 100 leukocytes per $\mu \mathrm{L}$ ). Positive rabies serology with the demonstration of serum neutralizing anti-rabies virus antibodies is diagnostic of rabies in a previously unimmunized individual, but may not become positive until a week or more after the onset of clinical illness. The presence of CSF neutralizing anti-rabies virus antibodies is considered diagnostic of rabies encephalitis. Rabies virus isolation is unusual except from brain tissues obtained by a diagnostic biopsy or post-mortem. Detection of rabies virus antigen or RNA in tissues or fluids is the usual method of making a laboratory diagnosis. A full thickness punch skin biopsy (usually $5-6 \mathrm{~mm}$ in diameter) containing hair follicles (minimum of ten) can be obtained from the posterior region of the neck at the hairline. Multiple sections should be prepared of the biopsy specimen with immunostaining for rabies virus antigen, which is usually performed using the direct fluorescent antibody technique. ${ }^{5,6}$ The skin biopsy specimen can also be analyzed for rabies virus RNA using reverse transcription polymerase chain reaction (RT - PCR) amplification. ${ }^{42}$ Further analysis, including sequencing, will allow specific identification of the rabies virus variant. Saliva specimens (collected with a sterile eyedropper pipette) can also be evaluated for rabies virus RNA using RT - PCR and these specimens have high sensitivity, whereas detection of rabies virus RNA using RT - PCR on CSF is less sensitive. Corneal impression smears have relatively low sensitivity for detection of rabies virus antigen. Negative laboratory tests, unless performed on brain tissues, do not exclude rabies, and further specimens may need to be obtained at a later time in the course of disease.

\section{MANAgEMENT OF RABIES}

Apart from the situation with organ and tissue transplantation, there is only a single report from Ethiopia indicating two cases with presumed human-to-human transmission of rabies. ${ }^{43}$ There have been no reports of transmission to health care workers, but this remains a significant and important theoretical concern. Hence, barrier techniques should be initiated as soon a diagnosis of rabies is suspected in order to prevent exposures of health care workers and family members, particularly in a critical care unit setting. Oral secretions are of particular concern because of the possibility that they may contain infectious rabies virus and result in transmission to family members or health care workers.
Rabies is almost invariably fatal, but there are situations in which a decision may be made to embark on aggressive approach to therapy that will require the full resources of a critical care unit and be associated with a high risk of failure. Most survivors of rabies have received doses of rabies vaccine prior to the onset of their clinical illness. ${ }^{30}$ The following should be considered a "favorable" factors for initiating an aggressive therapeutic approach: 1) therapy with dose(s) of rabies vaccine prior to the onset of illness, 2) young age, 3) healthy and immunocompetent individual, 4) rabies caused by a bat rabies variant (e.g., in contrast to a canine variant), 5) early presence of neutralizing anti-rabies virus antibodies in serum and CSF, and 6) mild neurological disease at the time of initiation of therapy. For example, an elderly immunosuppressed individual with advanced clinical disease (e.g., in coma) due to rabies would be a poor candidate for an aggressive approach. Laboratory tests for the detection of rabies virus antigen and RNA may be persistently negative in potential rabies survivors because viral clearance has already been initiated by the individual's immune response. A number of therapeutic options have been outlined in a viewpoint article by experts in clinical aspects of rabies and in basic rabies research. ${ }^{44}$ Therapy with a combination of agents was felt to be a more promising approach than using a single agent, and this approach has proved to be successful in diseases such as cancer and in other infectious diseases, including human immunodeficiency virus infection and chronic hepatitis $C$ virus infection. Specific agents discussed for therapeutic consideration include rabies vaccine, human rabies immune globulin, ribavirin, interferon- $\alpha$, and ketamine. The inclusion of ketamine was based on in vitro and rat model studies performed at Institut Pasteur in Paris in the early 1990s. ${ }^{45}$ More recent in vitro and mouse model studies now cast doubt on the efficacy of ketamine therapy ${ }^{46}$ and further studies are needed to determine whether there is significant efficacy of therapy with ketamine in an animal model of rabies before ketamine becomes a routine therapy for human patients with rabies.

In 2004 a 15-year-old female was bitten by a bat and about a month later she developed clinical rabies. ${ }^{47}$ She did not receive post-exposure rabies prophylaxis, including rabies vaccine. On presentation she had detectable neutralizing anti-rabies virus antibodies in her serum and CSF and all laboratory tests were negative for the detection of rabies virus antigen and RNA. She was treated with a therapeutic (induced) coma consisting of intravenous midazolam and supplemental phenobarbital to maintain a burst - suppression pattern on her electroencephalogram. She was also given antiviral therapy with ribavirin and also amantadine. Amantadine therapy was justified on the basis of an obscure in vitro report, ${ }^{48}$ although the risk of adverse effects would be expected to be very low with this therapy. Ketamine was given as a continuous intravenous infusion at a dosage of $48 \mathrm{mg} / \mathrm{kg} / \mathrm{day}$. The patient survived with only mild persisting neurological deficits. ${ }^{49}$ This therapeutic success has been followed by at least 20 documented failures to reproduce this therapeutic approach, dubbed the "Milwaukee Protocol," which has been relentlessly promoted (Table 3). ${ }^{37-39}$ Therapeutic coma for rabies or any other infectious disease has no clear scientific rationale and this therapy may only subject patients with rabies to a risk of developing adverse effects. Most concerning is the presence of abundant evidence of rabies virus 
Table 3: Cases of human rabies with treatment failures that used the main components of the "Milwaukee Protocol." (Adapted with permission from Jackson AC: Therapy in human rabies, in Research Advances in Rabies, Edited by A. C. Jackson. Advances in Virus Research 79:365 - 375, 2011;50 Copyright Elsevier.)

\begin{tabular}{|c|c|c|c|c|c|}
\hline $\begin{array}{l}\text { Case } \\
\text { No. }\end{array}$ & $\begin{array}{l}\text { Year of } \\
\text { Death }\end{array}$ & $\begin{array}{l}\text { Age and Sex of } \\
\text { Patient }\end{array}$ & Virus Source & Country & Reference \\
\hline 1 & 2005 & 47 male & kidney and pancreas transplant (dog) & Germany & Maier et al $(2010)^{29}$ \\
\hline 2 & 2005 & 46 female & lung transplant (dog) & Germany & Maier et al $(2010)^{29}$ \\
\hline 3 & 2005 & 72 male & kidney transplant (dog) & Germany & Maier et al $(2010)^{29}$ \\
\hline 4 & 2005 & unknown & $\operatorname{dog}$ & India & Bagchi $(2005)^{51}$ \\
\hline 5 & 2005 & 7 male & vampire bat & Brazil & $*$ \\
\hline 6 & 2005 & $20-30$ female & vampire bat & Brazil & $*$ \\
\hline 7 & 2006 & 33 male & $\operatorname{dog}$ & Thailand & Hemachudha et al (2006) ${ }^{52}$ \\
\hline 8 & 2006 & 16 male & bat & USA (Texas) & Houston Chronicle $(2006)^{53}$ \\
\hline 9 & 2006 & 10 female & bat & USA (Indiana) & Christenson et al $(2007)^{54}$ \\
\hline 10 & 2006 & 11 male & dog (Philippines) & USA (California) & Christenson et al $(2007)^{54}$ \\
\hline 11 & 2007 & 73 male & bat & Canada (Alberta) & McDermid et al $(2008)^{24}$ \\
\hline 12 & 2007 & 55 male & dog (Morocco) & Germany & Drosten $(2007)^{55}$ \\
\hline 13 & 2007 & 34 female & bat (Kenya) & The Netherlands & van Thiel et al $(2009)^{36}$ \\
\hline 14 & 2008 & 5 male & $\operatorname{dog}$ & Equatorial Guinea & Rubin et al $(2009)^{57}$ \\
\hline 15 & 2008 & 55 male & bat & USA (Missouri) & $\begin{array}{l}\text { Pue et al }(2009)^{58} \\
\text { Turabelidze et al }(2009)^{59}\end{array}$ \\
\hline 16 & 2008 & 8 female & cat & \begin{tabular}{|l} 
Colombia \\
\end{tabular} & Juncosa $(2008)^{60}$ \\
\hline 17 & 2008 & 15 male & vampire bat & Colombia & Badillo et al $(2009)^{61}$ \\
\hline 18 & 2009 & 37 female & dog (South Africa) & Northern Ireland & Hunter et al $(2010)^{62}$ \\
\hline 19 & 2009 & 42 male & $\operatorname{dog}$ (India) & USA (Virginia) & Troell et al $(2010)^{63}$ \\
\hline 20 & 2010 & 11 female & cat & Romania & $* *$ \\
\hline
\end{tabular}

* Personal communication from Dr. Rita Medeiros, University of Para, Belem, Brazil; ** Personal communication from Dr. Mihai A. Turcitu, Institute for Diagnosis and Animal Health, National Reference Laboratory for Rabies, Bucharest, Romania

antigen ${ }^{24}$ and/or high copies numbers of rabies virus RNA $^{29}$ in the post-mortem brains of therapeutic failures, including one patient who had complete loss of neurons in the cerebral cortex at autopsy ${ }^{24}$ and extensive loss of brainstem neurons (Dr. Christopher Power, personal communication). These reports provide abundant evidence that the therapy has failed to produce clearance of rabies virus from the brain. New approaches to the therapy of human rabies are needed rather than repeating this flawed therapy.

\section{Conclusions}

Rabies continues to be an international public health problem. The diagnosis of rabies needs to be considered even in the absence of a known animal exposure. Appropriate diagnostic laboratory testing should be performed in order to confirm a diagnosis of rabies, including rabies serology and testing of specimens, including saliva and skin biopsies, for the detection of rabies virus antigen and RNA. There is no known effective therapy for rabies and new approaches need to be developed in light of repeated failures of the Milwaukee Protocol.

\section{REFERENCES}

1. Lentz TL, Burrage TG, Smith AL, Crick J, Tignor GH. Is the acetylcholine receptor a rabies virus receptor? Science. 1982; 215:182-4.

2. Tsiang H. Evidence for an intraaxonal transport of fixed and street rabies virus. J Neuropathol Exp Neurol. 1979;38:286-96.
3. Ceccaldi PE, Gillet JP, Tsiang H. Inhibition of the transport of rabies virus in the central nervous system. J Neuropathol Exp Neurol. 1989;48:620-30.

4. Jackson AC, Ye H, Phelan CC, et al. Extraneural organ involvement in human rabies. Lab Invest. 1999;79:945-51.

5. Bryceson ADM, Greenwood BM, Warrell DA, et al. Demonstration during life of rabies antigen in humans. J Inf Dis. 1975;131: 71-4.

6. Warrell MJ, Looareesuwan S, Manatsathit S, et al. Rapid diagnosis of rabies and post-vaccinal encephalitides. Clin Exp Immunol. 1988;71:229-34.

7. Ross E, Armentrout SA. Myocarditis associated with rabies: report of a case. N Engl J Med. 1962;266:1087-9.

8. Cheetham HD, Hart J, Coghill NF, Fox B. Rabies with myocarditis: two cases in England. Lancet. 1970;1:921-2.

9. Raman GV, Prosser A, Spreadbury PL, Cockcroft PM, Okubadejo OA. Rabies presenting with myocarditis and encephalitis. J Infect. 1988;17:155-8.

10. Jackson AC. Pathogenesis. In: Jackson AC, Wunner WH, editors. Rabies. San Diego: Academic Press; 2002. p. 245-82.

11. Rossiter JP, Jackson AC. Pathology. In: Jackson AC, Wunner WH, editors. Rabies. 2nd ed. London: Elsevier Academic Press; 2007. p. 383-409.

12. Jackson AC, Lopez-Corella E. Images in clinical medicine: rabies. N Engl J Med. 1996;335:568.

13. Blanton JD, Palmer D, Rupprecht CE. Rabies surveillance in the United States during 2009. J Am Vet Med Assoc. 2010;237: 646-57.

14. Jackson AC. Update on rabies. Research and Reports in Tropical Medicine. 2011;2:31-43.

15. Dempster G, Grodums EI, Bayatpour M, Zbitnew A. A human case of unsuspected rabies in Saskatchewan diagnosed by virus isolation. Can J Public Health. 1972;63:215-18. 
16. King DB, Sangalang VE, Manuel $R$, Marrie $T$, Pointer AE, Thomson AD. A suspected case of human rabies - Nova Scotia. Can Dis Wkly Rep. 1978;4:49-51.

17. Picard AC. Human rabies acquired outside of Canada - Quebec. Can Dis Wkly Rep. 1984;10:177-8.

18. Webster WA, Casey GA, Charlton KM, Picard AC, McLaughlin B. Human rabies acquired outside of Canada. Can Dis Wkly Rep. 1985;11:13-14.

19. Dolman CL, Charlton KM. Massive necrosis of the brain in rabies. Can J Neurol Sci. 1987;14:162-5.

20. Webster WA, Casey GA, Charlton KM, Sayson RC, McLaughlin B, Noble MA. A case of human rabies in western Canada. Can J Public Health. 1987;78:412-13.

21. Turgeon N, Tucci M, Teitelbaum J, et al. Human rabies - Quebec, Canada, 2000. JAMA. 2000;285:160-1.

22. Despond O, Tucei M, Gregoire M, Teitelbaum JS, Turgeon N. Rabies in a nine-year-old child: the myth of the bite. Can J Infect Dis. 2002;13:121-5.

23. Parker R, McKay D, Hawes C, et al. Human rabies, British Columbia - January 2003. Can Commun Dis Rep. 2003;29: 137-8.

24. McDermid RC, Saxinger L, Lee B, et al. Human rabies encephalitis following bat exposure: failure of therapeutic coma. Can Med Assoc J. 2008;178:557-61

25. Blanton JD, Robertson K, Palmer D, Rupprecht CE. Rabies surveillance in the United States during 2008. J Am Vet Med Assoc. 2009;235:676-89.

26. Jackson AC, Fenton MB. Human rabies and bat bites (Letter). Lancet. 2001;357:1714.

27. Srinivasan A, Burton EC, Kuehnert MJ, et al. Transmission of rabies virus from an organ donor to four transplant recipients. $\mathrm{N}$ Engl J Med. 2005;352:1103-11.

28. Burton EC, Burns DK, Opatowsky MJ, et al. Rabies encephalomyelitis: clinical, neuroradiological, and pathological findings in 4 transplant recipients. Arch Neurol. 2005;62:873-82.

29. Maier T, Schwarting A, Mauer D, et al. Management and outcomes after multiple corneal and solid organ transplantations from a donor infected with rabies virus. Clin Infect Dis. 2010;50: 1112-19.

30. Jackson AC. Human disease. In: Jackson AC, Wunner WH, editors. Rabies. 2nd ed. London: Elsevier Academic Press: 2007. p. 309-40.

31. Sureau P, Portnoi D, Rollin P, Lapresle C, Chaouni-Berbich A Prevention of inter-human rabies transmission after corneal graft (French). Comptes Rendus de l'Académic des Sciences III, Sciences de la Vie. 1981;293:689-92.

32. Vetter JM, Frisch L, Drosten C, et al. Survival after transplantation of corneas from a rabies-infected donor. Cornea. 2011;30:241-4.

33. Warrell DA. The clinical picture of rabies in man. Trans $R$ Soc Trop Med Hyg. 1976;70:188-95.

34. Warrell DA, Davidson NM, Pope HM, et al. Pathophysiologic studies in human rabies. Am J Med. 1976;60:180-90.

35. Hattwick MAW. Human rabies. Public Health Rev. 1974;3:229-74

36. Kureishi A, Xu LZ, Wu H, Stiver HG. Rabies in China: recommendations for control. Bull WHO. 1992;70:443-50.

37. Bhatt DR, Hattwick MAW, Gerdsen R, Emmons RW, Johnson HN Human rabies: diagnosis, complications, and management. Am J Dis Child. 1974;127:862-9.

38. Hantson P, Guerit JM, de Tourtchaninoff $M$, et al. Rabies encephalitis mimicking the electrophysiological pattern of brain death. A case report. Eur Neurol. 1993;33:212-17.

39. Awasthi M, Parmar H, Patankar T, Castillo M. Imaging findings in rabies encephalitis. A J N R Am J Neuroradiol. 2001;22:677-80.

40. Pleasure SJ, Fischbein NJ. Correlation of clinical and neuroimaging findings in a case of rabies encephalitis. Arch Neurol. 2000;57: $1765-9$.

41. Laothamatas J, Sungkarat W, Hemachudha T. Neuroimaging in rabies. Adv Virus Res. 2011;79:309-27.

42. Dacheux L, Reynes JM, Buchy P, et al. A reliable diagnosis of human rabies based on analysis of skin biopsy specimens. Clin Infect Dis. 2008;47:1410-17.
43. Fekadu M, Endeshaw T, Alemu W, Bogale Y, Teshager T, Olson JG Possible human-to-human transmission of rabies in Ethiopia. Ethiop Med J. 1996;34:123-7.

44. Jackson AC, Warrell MJ, Rupprecht CE, et al. Management of rabies in humans. Clin Infect Dis. 2003;36:60-3.

45. Lockhart BP, Tsiang H, Ceccaldi PE, Guillemer S. Ketaminemediated inhibition of rabies virus infection in vitro and in rat brain. Antivir Chem Chemother. 1991;2:9-15.

46. Weli SC, Scott CA, Ward CA, Jackson AC. Rabies virus infection of primary neuronal cultures and adult mice: failure to demonstrate evidence of excitotoxicity. J Virol. 2006;80 10270-3.

47. Willoughby RE, Jr., Tieves KS, Hoffman GM, et al. Survival after treatment of rabies with induction of coma. N Engl J Med. 2005; 352:2508-14

48. Superti F, Seganti L, Pana A, Orsi N. Effect of amantadine on rhabdovirus infection. Drugs Exptl Clin Res. 1985;11:69-74.

49. Hu WT, Willoughby RE, Jr., Dhonau H, Mack KJ. Long-term follow-up after treatment of rabies by induction of coma (Letter). N Engl J Med. 2007;357:945-6.

50. Jackson AC. Therapy of human rabies. In: Jackson AC, editor. Research advances in rabies. Adv Virus Res. 2011;365-75.

51. Bagchi S. Coma therapy. The Telegraph (Calcutta). 2005 Jul 4

52. Hemachudha T, Sunsaneewitayakul B, Desudchit T, et al. Failure of therapeutic coma and ketamine for therapy of human rabies. J Neurovirol. 2006;12:407-9.

53. Houston Chronicle. Rabies, human - USA (Texas). ProMED-mail. 20060513.1360. 2006 May 13 [cited 2011 Mar 22]. Available from http://www.promedmail.org

54. Christenson JC, Holm BM, Lechlitner S, et al. Human rabies-Indiana and California, 2006. MMWR Morb Mortal Wkly Rep. 2007:56:361-5

55. Drosten C. Rabies - Germany (Hamburg) ex Morocco. ProMEDmail. 20070419.1287. 2007 Apr 19 [cited 2011 Mar 22]. Available from http://www.promedmail.org.

56. van Thiel PP, de Bie RM, Eftimov F, et al. Fatal human rabies due to Duvenhage virus from a bat in Kenya: failure of treatment with coma-induction, ketamine, and antiviral drugs. PLoS Negl Trop Dis. 2009;3:e428.

57. Rubin J, David D, Willoughby RE, Jr., et al. Applying the Milwaukee Protocol to treat canine rabies in Equatorial Guinea. Scand J Infect Dis. 2009;41:372-5.

58. Pue HL, Turabelidze G, Patrick S, et al. Human rabies - Missouri, 2008. MMWR Morb Mortal Wkly Rep. 2009;58:1207-9.

59. Turabelidze G, Pue H, Grim A, Patrick S. First human rabies case in Missouri in $\mathbf{5 0}$ years causes death in outdoorsman. Mo Med. 2009;106:417-19.

60. Juncosa B. Hope for rabies victims: unorthodox coma therapy shows promise. First a U.S. girl - and now two South American kids survive onset of the deadly virus. ScientificAmerican com. 2008 Nov 21 [cited 2011 Mar 23]. Available from: http://www.scientificamerican.com/

61. Badillo R, Mantilla JC, Pradilla G. Human rabies encephalitis by a vampire bat bite in an urban area of Colombia (Spanish). Biomédica. 2009;29:191-203.

62. Hunter $M$, Johnson $N$, Hedderwick $S$, et al. Immunovirological correlates in human rabies treated with therapeutic coma. J Med Virol. 2010;82:1255-65

63. Troell P, Miller-Zuber B, Ondrush J, et al. Human rabies - Virginia, 2009. MMWR Morb Mortal Wkly Rep. 2010;59:1236-8. 